\title{
The Law of Regional and Multilateral Agreements: How does Andean Community law relate to WTO rules?
}

\author{
REYES TAGLE, Yovana ${ }^{1}$ \\ Pontificia Universidad Católica del Perú
}

\begin{abstract}
The Andean Court of Justice (hereinafter the ACJ) has shown its interest in respecting the international obligations incumbent on Member States as parties to other treaties by considering these as sources of law in the Andean Community. The ACJ has also shown a certain openness to international agreements signed by Member States by asserting the need for consistent interpretation of Andean law in the light of these agreements. Nevertheless, ACJ concern for the unrestrictive application of Andean law by Member States is echoed in its case law. Such concern is justified as although the Andean Community is not a WTO member, the question of the applicability of WTO law in the Andean legal order has been raised by Member States, private parties and Andean institutions themselves. This paper deals with the manner in which the ACJ responded to the question. The paper finds that Andean institutions may use WTO law in the Andean Community so long as the application of Andean law is not jeopardized.

Research for this paper was funded by the Swiss Secretariat for Economic Affairs (SECO) under a partnership agreement with the World Trade Institute of the University of Bern, Switzerland.

Disclaimer: These papers have not been formally edited. Citations should refer to a "SECO Working Paper", with appropriate reference made to the author(s).
\end{abstract}

\section{WTO law as a source of law in the Andean Community}

The Andean Court of Justice (ACJ) has clarified the sources of community law in the Andean Community. It regards primary law represented by the foundational treaties and protocols, secondary law and public international law as sources of Andean community law. The ACJ has also recognized unwritten sources of community law, such as customary law and practice and general principles of law. Jurisprudence in application of community law has been seen as an instrument to guide the development of community law. ${ }^{2}$ The ACJ

\footnotetext{
${ }^{1}$ LL.D., LL.M., from the University of Helsinki, Finland. Lecturer on the Master’s Program on International Economic Law of the Pontificia Universidad Católica del Perú.
}

${ }^{2}$ ACJ Ruling 1-IP-96. 
regards international law as an indirect source of Andean law, making clear that the Andean Community is not bound by such a source. ${ }^{3}$

The ACJ has also recognized the international agreements signed by the Andean countries as sources of community law, ${ }^{4}$ showing to some extent an open attitude to other international legal systems. Specifically, WTO agreements are seen as a source of law in the Andean Community. ${ }^{5}$ In this connection, to reinforce its interpretation of intellectual property controversies, in its Ruling 2-AI-96 the ACJ accepted the importance of using the Agreement on Trade-Related Aspects of Intellectual Property Rights (TRIPS Agreement) as a means to provide important elements for the interpretation of intellectual property systems. It cited some of the provisions of this Agreement to back up its position. ${ }^{6}$ As regards the General Agreement on Tariffs and Trade (GATT), in its Ruling 5-IP-90 the ACJ noted that this legal instrument which has been the subject of interpretation by international jurisprudence and doctrine helps explain the meaning of fundamental concepts included in the Cartagena Agreement, such as commercial liberalization and trade restrictions, which are contrary to such liberalization. ${ }^{7}$ In the context of the analysis of the ACJ concerning the importance of the principle of free movement of goods, the ACJ has also referred to the provisions of the GATT concerning the prohibition of quantitative restrictions and stressed their importance, considering them to be fundamental provisions of the GATT. ${ }^{8}$

There are also cases in which the ACJ did not seek a solution based on WTO agreements but treated them as reference points in their reasoning to frame the background of the Andean rules. A good example is offered by the ACJ Ruling 114-AI-2004 where the ACJ used the TRIPS Agreement for these purposes. In the same case, the ACJ took into account the 2001 Doha Ministerial Declaration on the TRIPS Agreement and Public Health but merely quoted some of its paragraphs. In effect, the Court did not elaborate upon how those paragraphs were used in the case in question. Not surprisingly, consistent with its way of perceiving the relationship between Andean and WTO law, the ACJ also cited its case law concerning the hierarchical relationship between Andean and WTO law in this type of case. $^{9}$

These cases reveal that the ACJ has taken the WTO agreements as a reference point to interpret Andean rules in disputes. However, the ACJ has not explicitly employed the detail of WTO jurisprudence in order to develop its interpretations. It has merely cited the rules of

\footnotetext{
${ }^{3}$ ACJ Ruling 1-AN-97.p.15.

${ }^{4}$ In the European Union, international agreements signed by the Member States only, as Eckes notes, "can have effects in the European legal order. As is well-known, the European Convention on Human Rights (ECHR), a convention to which all the EU Member States but not the Union are parties... has long been used by the Court of Justice to fill the gaps in human rights protection under European law... But the Court has also conferred a sort of soft law status to other conventions to which only the Member States are parties...” Eckes, Christina. International Law as Law of the EU: the Role of the ECJ. CLEER Working Papers 2010/6.p.12. Available at: http://www.asser.nl/upload/documents/1212010_60145clee10-6web.pdf. (06.10.2014).

${ }^{5}$ ACJ Ruling 34-AI-2001.

${ }^{6}$ ACJ Ruling 2-AI-96.p.34.

${ }^{7}$ ACJ Ruling 5-IP-90.p.11.

${ }^{8}$ ACJ Ruling 3-AI-97. p.19. ACJ Ruling 5-IP-90.p.10.

${ }^{9}$ ACJ Ruling 114-AI-2004.p.36-39.
} 
the WTO agreements without showing further interest in how the WTO jurisprudence has concretely applied such rules.

As has been seen, the ACJ has not denied that international law is a source of law in the Andean Community. The ACJ has also established that in the event of legal gaps in the Andean legal order, the general principles of community law, the substantive law of the Member States and the principles of international law will be applied. It has added that, in a supplementary manner, use of the WTO provisions will be made subject to the compatibility of these multilateral norms with the principles and norms of the Andean Community. ${ }^{10}$ How this use of WTO provisions will be made is not clear. Who will determine the compatibility or incompatibility of multilateral norms with the Andean legal order in order to use WTO rules in a supplementary manner? This question remains unanswered. It is the exclusive competence of the ACJ to construe Andean law. The condition of compatibility introduced by the ACJ does not find basis since such compatibility will not be declared by this judicial body. Thus, contrary to what the ACJ has argued, the use of WTO provisions most probably will be made as a guideline or a source for the interpretation of Andean law without explicitly making the analysis of compatibility. For reasons earlier noted, this is indeed how the ACJ has referred to WTO agreements.

Against this background, it is notable that the ACJ has pursued a different course as regards the Treaty on the Functioning of the European Union (TFUE) by considering it as a source of law in the Andean Community. Interestingly, when addressing the principle of free movement of goods, the ACJ recognizes that the Cartagena Agreement does not include a substantive provision for measures of equivalent effect to quantitative restrictions as Article 34 of the TFUE does. However, the ACJ takes the view that this provision of the TFEU, together with the provisions on quantitative restrictions of the GATT/WTO, can constitute a valuable supplementary source of law. ${ }^{11}$ If both rules are deemed a supplementary source of law, the question is: can a provision of the TFUE have the same standing in the Andean Community as a WTO rule? Taking into account that all the Member States of the Andean Community are Members of the WTO, and the fact that the ACJ has acknowledged that international treaties signed by the Andean states are sources of community law, ${ }^{12}$ the reference to the GATT is understandable. The ACJ has not further developed its judgment delivered in the 1990s, considering the TFEU as a supplementary source of law in the Andean Community. The ACJ should review its case law concerning the consideration of a treaty which has not been signed by the Andean states, such as the TFUE, as a supplementary source of law and analyze the implications of such recognition.

Interestingly, both the General Secretariat and the ACJ have adopted the definition of measures of equivalent effect used by Article 34 of the TFUE rather than those employed by Article XI of the GATT. Moreover, the ACJ has not used the jurisprudence of the GATT/WTO when it has had the chance to utilize European Court of Justice (hereinafter the ECJ) case law. For example, it has shown its preference for the utilization of ECJ case law as regards the scope of the principle of the free movement of goods, in particular, the ECJ definition of measures of equivalent effect to quantitative restrictions and the principle

\footnotetext{
${ }^{10}$ ACJ Ruling 118-AI-2003. p.47.

${ }^{11}$ ACJ Ruling 3-AI-96. The ACJ reaffirmed this position in its Ruling 1-AI-97.p.14.

12 ACJ Ruling 2-AI-96.
} 
of proportionality. These Andean institutions endorsed the ECJ Dassonville formula ${ }^{13}$ instead of resorting to the jurisprudence of the WTO Panels and Appellate Body concerning Article XI of the GATT.

Subsequently, the ACJ has also referred to the principle of national treatment enshrined in the WTO in other rulings. Together with the GATT/WTO, the ACJ mentioned the 1980 Treaty of Montevideo which created the Latin American Integration Association (ALADI). In view of these cases, ${ }^{14}$ one may argue that the ACJ wanted to highlight the importance of the principle of national treatment to the Member States' international trade relations to the extent that such a principle was incorporated not only in the Cartagena Agreement but also in the international agreements that they individually subscribed to. However, no further analysis has been undertaken as to how the WTO principle interacts with the scope of the national treatment principle set forth by the Cartagena Agreement. The reference serves to show in a broader context the objective of such a principle. Likewise, the ACJ has also indicated that the WTO Schedules of concession are based on the Harmonized System adopted by the World Customs Organization. Essentially, the reference to the WTO in this particular case is aimed at exhibiting the relevance of the Harmonized System in international fora without touching on the WTO substantive rules. ${ }^{15}$ It follows from these cases that the WTO is utilized in some cases where the ACJ wants to highlight the aims and important role of some international rules and practices without employing the WTO provision on the substance of the case.

Additionally, the ACJ has emphasized the fundamental role played by the principle of most favored nation by referring to its recognition in Article I of the GATT. ${ }^{16}$ The ACJ outlined the scope and characteristics of Article I of the GATT and surprisingly the Court determined that Article 139 (ex-Article 155) of the Cartagena Agreement contained such a principle with similar characteristics, objectives, scope and consequences to that of the GATT. ${ }^{17}$ The present case is cited to illustrate that, in its Ruling 16-AN-2002, the ACJ compared the Andean and WTO provisions and found similarity between the manner in which the most favorable nation principle was regulated in both legal orders. It should be added that although the case involved an annulment procedure, no Andean provision was questioned in the light of WTO law in the case at hand.

\footnotetext{
${ }^{13}$ Reyes Tagle, Yovana. Free Movement of Goods in the Andean Community: How far can Dassonville go? SECO/WTI Academic Cooperation Project Working Paper Series 8/2012. Available at: http://www.wti.org/fileadmin/user_upload/wti.org/7_SECOWTI_Project/Publications/Reyes\%20Tagle\%20FMG\%20dic\%202012.pdf.

${ }^{14}$ ACJ Ruling 111-IP-2011.p.16-17. See also ACJ Ruling 11-IP-2008.p.18; ACJ Ruling 12-IP-2008.p.11; ACJ Ruling 13-IP-2008; ACJ Ruling 14-IP-2008.p.13; ACJ Ruling 15-IP-2008.p.11; ACJ Ruling 190-IP2007.p.12; ACJ Ruling 191-IP-2007.p.12; ACJ Ruling 192-IP-2007.p.12; ACJ Ruling 193-IP-2007.p.11; ACJ Ruling 193-IP-2007.p.13.

${ }^{15}$ ACJ Ruling 17-IP-2008.p.11.

${ }_{17}^{16}$ ACJ Ruling 16-AN-2002.p.17.

${ }^{17}$ ACJ Ruling 16-AN-2002.p.18.
} 


\section{WTO and the principle of direct effect in the Andean Community}

\subsection{The concept of direct effect in the Andean Court of Justice case law}

The Andean legal system does not contain a provision as regards the principle of direct effect of community law. However, the ACJ stands by and applies the principle inspired by ECJ case law concerning the direct effect of Community law established in its landmark Van Gend en Loos case. ${ }^{18}$ On this basis, the ACJ held that Andean legislation conferred rights on individuals which they can directly invoke before their national courts and which these are bound to protect. The norms that are part of the Andean legal order have direct effect from the date of their publication in the Official Gazette of the Andean Community. ${ }^{19}$

Antoniadis points out that

"...the definition of direct effect is not without controversy...In fact, within the Community context, the 'objective' or 'classic' definition of direct effect refers to a legal provision granting rights to individuals which must be upheld by national courts...It has been argued that direct effect not only provides the norm that governs a given case, it provides, in addition, the standard for legal review...The generic use of the concept of direct effect to include the standard of review has been particularly popular in the GATT/WTO context, owing to the participation of Member States in proceedings before the Court for which the classic definition of direct effect would clearly have been inadequate." 20

The European Court of Justice has denied direct effect to WTO law, ${ }^{21}$ although this position has evoked criticism, ${ }^{22}$ and its grounds of justification for such denial has been seen as "not legally persuasive" 23 . But both the EU and the EU members are bound by the international agreements signed by the EU. ${ }^{24}$ However, for an international organization such as the Andean Community which is not a WTO member, unlike the European Union, is it necessary to declare that an international agreement, e.g. a WTO agreement, lacks direct effect in the Andean legal order? The ACJ has not developed a case law on the direct effect of international law in the Andean Community; that is, it has not explicitly analyzed any specific criteria to grant or deny direct effect to international treaties as the ECJ has. Hence, it is not clear how the ACJ conceptualizes the direct effect of international agreements.

\footnotetext{
${ }^{18}$ ACJ Ruling 3-A-96.p.14. See also ACJ Ruling 7-AI-99.p.11-13; ACJ Ruling 2-IP-90.p.6.

${ }^{19}$ ACJ Ruling 3-A-96.p.14. ACJ Ruling 7-AI-99.p.13.

${ }^{20}$ Antoniadis, Antonis. The European Union and WTO law: a nexus of reactive, coactive, and proactive approaches. World Trade Review, 6 (1) March 2007.p.46-47.

${ }^{21}$ The denial of direct effect to WTO rules does not amount to an overlooking of the importance of the multilateral system for the EU. As Jacobs puts it, "the WTO plays a foundational role for the EU: indeed the EU has accepted the WTO as the foundation of its commercial policy and its economic relations with third states.” Jacobs, Francis G. The State of International Economic Law: Re-Thinking Sovereignty in Europe. Journal of International Economic Law, 11(1), March 2008.p.16.

${ }^{22}$ Berkey, Judson Osterhoudt. The European Court of Justice and Direct Effect for the GATT: A Question Worth Revisiting. 9 European Journal of International Law, 1998.p.626.

${ }^{23}$ Bronckers, Marco. The Domestic Law Effect of the WTO in the EU - a dialogue with Jacques Bourgeois. The International Law Annual, 2013.p. 26.

${ }^{24}$ Article 216 numeral 2 of the TFEU.
} 
Apparently, the ACJ applies the same concept of direct effect borrowed from the ECJ developed for the application of Community law. As Errico puts it: "It may be natural to presume that the test established in Van Gend for Treaty and secondary law provisions in the EU would also apply to international agreements. However, the ECJ has been careful to note that Community legislation is fundamentally different from international obligations, despite the binding nature of the latter." 25 In the Andean Community, the ACJ needs to take into consideration the different nature of Andean law and international treaties signed by Member States in the context of the analysis of direct effect.

\subsection{The denial of direct effect to WTO law}

The Andean Community members have shown their concern over the potential conflict between the obligations that they have assumed in the Andean Community with those of the multilateral system as embodied by the WTO. They have consistently stated that they are bound not only by Andean legislation but also by WTO agreements. As a consequence, there have been attempts to achieve the recognition of direct effect for WTO rules in the Andean Community, such as when Andean Community members asked the General Secretariat and the ACJ for the recognition and application of WTO rules, ${ }^{26}$ questioning the legality of Andean rules in the light of WTO agreements, ${ }^{27}$ and demanding that the ACJ respect WTO law.

A number of cases have dealt with the question of how to enforce WTO law in the Andean Community. In this respect, the ACJ has referred to the issue of direct effect and claimed that international treaties signed by the Member States, such as the TRIPS Agreement, do not have direct effect in the Andean Community. ${ }^{28}$ The ACJ focused on the characteristics of the Andean legal order and found the explanation of its position in the autonomy of the Andean system which, in the ACJ's view, means that this system does not derive from either the national legal order of the Member States or the international agreements that they sign. ${ }^{29}$ Because of that focus, the ACJ has, on several occasions, refused to be bound by the international agreements signed by its Member States and has insisted that WTO law is not binding for the Andean Community. ${ }^{30}$ The ACJ took the same view regarding the 1910 Inter-American Convention of Buenos Aires. ${ }^{31}$

\footnotetext{
${ }^{25}$ Errico, John.The WTO in the EU: Unwinding the Knot. 44Cornell International Law Journal, 2011.p.183.

${ }^{26}$ ACJ Ruling 34-AI-2001.p.8. ACJ Ruling 118-AI-2003.p.47.

27 Some Andean countries have gone further, to the extent of claiming the existence of incompatibility between some Andean rules with WTO agreements. In the Peru antidumping case, Peru held that the Andean Decision 283, which was adopted prior to the entrance into force of the WTO Agreements, was not notified to the WTO owing to the fact that such a Decision contains requirements which are contrary to the obligations assumed by the Andean states in the WTO. It further stated that if the Andean countries had wanted to modify the Decision to make it compatible with WTO rules, they should have done so. See ACJ Ruling 35-AN2003.p.26.

${ }^{28}$ ACJ Ruling 036-IP-2009; ACJ Ruling 115-IP-2009.p.16; ACJ Ruling 217-IP-2005.p.8.

${ }^{29}$ ACJ Ruling 036-IP-2009.

${ }^{30}$ ACJ Ruling 03-IP-2014 para. 38. See also ACJ Ruling 36-IP-2009.p.6; ACJ Ruling 115-IP-2009.p.16; ACJ Ruling 80-IP-2009.p.6; ACJ Ruling 106-IP-2006.p.19.

${ }^{31}$ ACJ Ruling 81-IP-2009.p.7.
} 
This ACJ approach as regards the WTO agreements differs from that of the ECJ. Eckes notes that, "By creating the concept of functional succession in the case of International Fruit Company, the Court of Justice accepted, even before the Community had become a party, that the Community is fully bound by 1947 GATT obligations." 32 The ECJ has also recognized other international treaties as legally binding for the EU although the organization was not party to such treaties. The European Convention on Human Rights is an outstanding case in point. ${ }^{33}$ By contrast, in the case of the Andean Community ACJ case law shows that since any international agreement is binding only for the parties, and the Andean Community is not a WTO member, WTO agreements do not create any right or obligation for the Community itself. Besides, it is worth observing that as a regional agreement the Andean Community needs to meet certain WTO requirements, in particular the provisions of the Enabling Clause which is the regime under which this regional organization conducted its notification as a Customs Union to the GATT in $1990 .^{34}$

Notably, some Andean countries and private parties have sought to rely on WTO agreements to support the application of national laws which favor their interests. For instance, Peru enacted a Supreme Decree interpreting the former Andean Decision 344 which established the Common Regime on Intellectual Property in the Andean Community (now Decision 486). Although the then Decision 344 did not include second use patents as patentable subject matter, the new Peruvian law accepted their patentability. As a result, the General Secretariat issued its Resolutions 358 and 406 and took the view that second use patents were not allowed under Decision 344. It therefore deemed that Peruvian law breached community law. The case, also known as the Viagra case, was brought against Peru before the ACJ by the General Secretariat. Both Peru and the patent holder invoked the TRIPS Agreement to argue that such patents, which were allowed under Peruvian law, were consistent with the Agreement. Strangely, Peru, supported by private parties, among them Pfizer, claimed before the ACJ that the Andean Community was violating the TRIPS Agreement as regards the granting of second use patents. Pfizer's submission proceeded in a similar vein, requesting the ACJ to recognize and declare that the interpretation afforded by the General Secretariat denying second use patents was contrary to Articles 27.1 and 70.2 of the TRIPS Agreement. Thus, Peru and Pfizer requested the ACJ to declare the incompatibility between Andean secondary law and the WTO rules. ${ }^{35}$ A number of private parties made submissions that were supportive of the Peruvian position. It should be mentioned that the Andean Community has not assumed obligations in the WTO. Therefore, the Community itself cannot be found to be in violation of a WTO agreement.

The ACJ did not concede the defendant's arguments for the following reasons: First, the ACJ did not accept the coexistence of two different international legal orders which Member States could conveniently choose between, disregarding the less favorable. Second, the ACJ noted that Member States cannot pass national laws aimed at making community law compatible with other international agreements when, in their view, there exists some incompatibility. Third, the ACJ pointed out that those arguments raised by the

\footnotetext{
${ }^{32}$ Eckes, Christina. Op.cit.

33 Jacobs, Francis G. Op.cit.p.17, 19.

${ }^{34}$ Information about the notification of the Andean Community in the WTO is available at: http://rtais.wto.org/UI/PublicShowMemberRTAIDCard.aspx?rtaid=127. (16.09.2014).

${ }^{35}$ ACJ Ruling 89-AI-2000.
} 
defendant violated the principle of autonomy and supremacy of Community law. ${ }^{36}$ This last part of the Court's statement is more controversial. Was there a violation of these principles? The ACJ conceptualizes the principle of autonomy as an effect and complement of the principle of supremacy, emphasizing that the validity of Andean legal order does not depend on any other legal order. ${ }^{37}$ Additionally, the ACJ has asserted that the principle of autonomy is fundamental to the principle of supremacy. ${ }^{38}$ This may explain why the ACJ deemed that the defendant's arguments violated both principles. Arguably, the fact that the defendant and the private parties invoked the TRIPS Agreement and questioned the legality of an Andean norm in the light of this Agreement does not violate the principle of supremacy of Andean law. Rather, this is part of the direct effect argument that the ACJ should have directly addressed before declaring the supremacy of Andean law. For that matter, after assessing whether the Andean Community is bound by WTO law, the ACJ should have reviewed whether the WTO was capable of making Andean law invalid based on the question of direct effect. ${ }^{39}$ In holding that the arguments raised by the defendant concerning the applicability of the TRIPS Agreement breached the principle of supremacy, the ACJ did not adequately distinguish between the question of direct effect of the WTO agreements, namely whether or not those agreements could be used as a standard for judicial review, and the issue of supremacy of the Andean legal order.

What is particularly noteworthy is that in its ruling, the ACJ did not even discuss the possible compatibility or incompatibility of Andean rules with the TRIPS Agreement. The ACJ decided on the relationship between the Peruvian and community law and ruled that Peru violated community law. The autonomy of the Andean legal order became the focus of the ACJ stance, and on these grounds it concluded that it was inappropriate to compare the Andean provisions with the TRIPS Agreement. Having said that, the ACJ added that such a comparison was even more inappropriate since the desire of the defendant was the declaration of the supremacy of the TRIPS Agreement over the Andean Decision 344 and therefore the inapplicability of the latter. The ACJ rejected this option. ${ }^{40}$ Neither will such a comparison be made ex officio. Consequently, this judgment implies that although the ACJ has not explicitly made this point, WTO law will not be used as a standard for legal review in the Andean Community when questioning Community law. However, this approach is based on the recognition of the autonomy of Community law rather than in the denial of direct effect. As indicated above, the concept of autonomy of the Andean legal order articulated by the ACJ is that such a legal order derives from the foundational treaties of the Andean Community rather than the internal legal order of the Member States or the

\footnotetext{
${ }^{36}$ ACJ Ruling 89-AI-2000.

${ }^{37}$ ACJ Ruling 115-IP-2009.p.16.

${ }^{38}$ ACJ Ruling 80-IP-2009.p.5-6. See also ACJ Ruling 13-IP-2009.p.15.

39 The ECJ followed this approach in the Joined Cases C-21/72 \& C-24/74, Int'l Fruit Company NV v. Produktschap voor Groenten en Fruit 1972 E.C.R. I-1219. Errico observes that in the International Fruit case "The ECJ stated that the international law relied upon could invalidate Community law only if it satisfied two conditions: first, the provision of international law must bind the Community... second, the provision must be "capable of conferring rights on citizens of the Community which they can invoke before the courts.” Errico, John. Op.cit.p.184. Notwithstanding the differences between the Andean and EU legal order with respect to WTO law, the ACJ needed to provide a line of reasoning concerning the direct effect of WTO law as the ECJ did. That is not to say that the ACJ should endorse the ECJ case law and accept, for example, that the Andean Community is bound by the WTO agreements even when the Community is not a WTO member, as the ECJ did, because account should be taken of the particular features of the Andean legal system.

${ }^{40}$ ACJ Ruling 89-AI-2000.
} 
international agreements that they signed. Arguably, the autonomy of the Andean legal order is not impinged on if a comparison is made in order to ascertain the compatibility of such legal order with the WTO agreements or any other international agreement. For instance, the ECJ has recognized that international agreements prevail over secondary law ${ }^{41}$ and has even acknowledged direct effect to some international agreements. ${ }^{42}$ Such recognition does not imply that the EU legal order is no longer autonomous and independent of international law. The ACJ itself compared the Andean legal order with an international treaty in its Ruling 1-IP-96, as will be discussed below. In doing so, the ACJ did not express concern regarding the autonomy of the Andean legal order.

Interestingly, in its ruling, the ACJ glossed over the question of whether the Member States or individuals have the right to question the lawfulness of an Andean rule relying on WTO agreements. The ACJ should have developed a reasoned opinion concerning the right of Member States or individuals to challenge the lawfulness of an Andean rule on WTO grounds. Instead, the ACJ showed its great concern over the possibility of setting aside Andean law to apply a national law which the defendant considered was consistent with WTO rules. The ACJ did not want to leave the Member States the freedom to define and choose when and under which conditions Andean law would be applied when faced with the WTO rules. Consequently, it reaffirmed the supremacy of Community law over the WTO agreements before solving the question of direct effect as a condition of judicial review.

The ACJ decision met with some resistance from the Member States which showed their unwillingness to accept the ACJ's arguments. In a related case involving Ecuador, the ACJ dealt with similar claims over the obligation of the Andean countries to apply WTO rules despite the existence of Andean law which did not recognize the granting of second use patents. Again, the national law of Ecuador allowed the granting of second use patents. The General Secretariat instituted an action at the ACJ alleging that Ecuador had breached Andean law. At this judicial stage, Ecuador made similar remarks to Peru and favored the application of WTO law. Ecuador invoked the TRIPS Agreement, arguing that such an agreement allowed the granting of second use patents and prevented Andean states from refusing to grant them. Ecuador went even further, demanding the application of WTO rules by requesting that the ACJ respect this Agreement. ${ }^{43}$

Once again, the question of enforcement of WTO law in the Andean legal system arose in this case. Pfizer, one of the supporters of the defendant, claimed that it was unacceptable that in an alleged collision between Andean secondary law and the universal treaty of the WTO, in particular the TRIPS Agreement, Andean law should prevail. Pfizer invoked the Andean Decision 458 and claimed that the institutions of the Andean Community were bound to protect intellectual property rights in accordance with both the Andean Decisions

\footnotetext{
${ }^{41}$ The ECJ held that "the primacy of international agreements concluded by the Community over provisions of secondary Community legislation means that such provisions must, so far as is possible, be interpreted in a manner that is consistent with those agreements”. ECJ, Case C-61/94, Commission v. Germany [1996] para.52.

42 Olsen, Birgitte Egelund and Steinicke, Michael. The WTO and the EU. In Olsen, Birgitte Egelund, Steinicke, Michael, and Sorensen, Karsten Engsig (eds): WTO Law. From A European Perspective. Forlaget Thomson: Copenhagen, 2006.p.114.

${ }^{43}$ ACJ Ruling 34-AI-2001.
} 
and public international law, in particular those rights included in treaties. ${ }^{44}$ In other words, Pfizer requested that the Andean institutions oversee the fulfillment of the TRIPS Agreement. The ACJ rejected these arguments and reaffirmed its established precedents. Furthermore, the ACJ recalled that Member States had transferred competences to the Andean Community in specific matters such as intellectual property. Owing to this transfer of competences, in the ACJ's view the legislative powers of the Member States are limited and therefore these states are not entitled to issue rules or make international commitments which are contrary to community law. ${ }^{45}$ The ACJ did not explicitly declare that the TRIPS Agreement was inconsistent with Andean legislation. However, unlike in its previous ruling involving Peru, the question of direct effect was taken up by the ACJ, which merely affirmed that the TRIPS Agreement did not have direct effect without specifying the implications of this statement. ${ }^{46}$

Moreover, in a similar case, this time involving Venezuela, ${ }^{47}$ this former Andean Community member shared Peru and Ecuador's thoughts on the applicability of the TRIPS Agreement, arguing that the General Secretariat cannot establish prohibitions of patentability which differ from Andean law and the TRIPS Agreement. ${ }^{48}$ Venezuela not only invoked the WTO agreements but also contested the lawfulness of the former Andean Decision 344 to justify the granting of second use patents. Again, the matter was submitted to the ACJ and this Court confirmed its previous case law. ${ }^{49}$ It is worth observing that Colombia did not join the other three Andean countries on the granting of second use patents. $^{50}$

On the subject of direct effect one fact is noteworthy. None of these three Member States had any doubt concerning their right to invoke WTO rules before the ACJ to question the legality of Andean rules. Naturally, they needed all the available options to defend their national laws and found the WTO rules one way to attain that objective. Additionally, none of them clearly spelled out convincing and persuasive arguments as to why the ACJ as an Andean juridical body had to ensure the full respect and enforcement of the international agreements, such as the WTO agreements, that they had individually signed.

Overall, then, this investigation into the Court case law reveals that it is settled case law that the Andean countries cannot justify a breach of Andean law on WTO grounds. Furthermore, the ACJ is not expected to assess the legality of Andean law in the light of WTO rules. As yet, the ACJ has limited itself to stating that the WTO lacks direct effect. Since the ACJ touched on the issue of direct effect, this case gave the ACJ a tailor-made

\footnotetext{
${ }^{44}$ ACJ Ruling 34-AI-2001.

45 ACJ Ruling 34-AI-2001.

${ }^{46}$ ACJ Ruling 34-AI-2001.

${ }^{47}$ Venezuela withdrew from the Andean Community in 2006.

${ }^{48}$ ACJ Ruling 1-AI-2001.p.7.

49 ACJ Ruling 1-AI-2001.p.38.

${ }^{50}$ It has been noted that "In Colombia, by contrast, the administrative agency was bolder. It rejected Pfizer's application, leading the company to appeal to the Council of State, which requested a preliminary ruling. The tribunal reiterated its interpretation of Andean law and the Colombian court implemented the ATJ's decision.” Helfer, Laurence R., Alter, Karen J., Guerzovich, M. Florencia. Islands of Effective International Adjudication: Constructing an Intellectual Property Rule of Law in the Andean Community. 109 American Journal of International Law, 2009.p.36. Available at: http://ssrn.com/abstract=1306318.
} 
opportunity to clarify the scope of its case law concerning the direct effect of WTO law. It is submitted that the ACJ should have seized the opportunity to clearly assert in a definite manner that neither Member States nor individuals can contest the legality of Andean rules in the light of WTO rules. This Court has not linked up the concept of direct effect with the question of judicial review in addressing the relationship between WTO and Andean law.

Likewise, it is noteworthy that in line with the mandate of the ACJ to construe Andean law and ensure its uniform application, this Andean institution should not recognize that an international agreement signed by the Member States has direct effect in the Andean Community. It is submitted that in the Andean context, the non-applicability or enforcement of WTO law in the Andean legal order derives from the fact that the Andean Community institutions do not have the competence to enforce or oversee the fulfillment of the international obligations assumed only by the Member States within the framework of the WTO or any other international treaty. The fact that the ACJ itself overruled the Resolution of the General Secretariat in the Peru antidumping case discussed below supports this proposition. The ACJ correctly envisaged that it was not the mandate of this Community institution to ensure the application of WTO rules.

\section{Supremacy of Andean law over national and international law}

\subsection{The concept of supremacy of Andean Community law}

Another facet of the debate over the relationship between WTO and Andean law is the hierarchy of one legal system over the other. Andean legislation is silent on the matter of supremacy of Andean law over domestic law or international agreements. ${ }^{51}$ The ACJ has analyzed the relationship between the Andean and the national legal system of the Member States. In this analysis, the ACJ followed ECJ case law concerning supremacy of European Union law over Member States' internal legal orders. The ACJ has long cited and built upon the ideas displayed in the ECJ Van Gend en Loos, ${ }^{52}$ Simmental, $^{53}$ and Costa $v$ Enel ${ }^{54}$ rulings to establish the principle of direct effect, direct applicability and supremacy of community law over national law. ${ }^{55}$ Consequently, in view of these cases, the ACJ reasoned that the Andean Community has created its own legal system which has become an integral part of the legal orders of its Member States. More concretely, the ACJ has

\footnotetext{
${ }^{51}$ It is worth observing that there are some international agreements which contain provisions concerning their hierarchical relationship with other international agreements. More importantly, they even provide for the supremacy of their rules over other international agreements or the supremacy of other international agreements over them. In this regard, Article 103 of the North American Free Trade Agreement (NAFTA) reads as follows: "1. The Parties affirm their existing rights and obligations with respect to each other under the General Agreement on Tariffs and Trade and other agreements to which such Parties are party.

2. In the event of any inconsistency between this Agreement and such other agreements, this Agreement shall prevail to the extent of the inconsistency, except as otherwise provided in this Agreement." See also Article 104 of the NAFTA Agreement. In the same vein, Article 103 of the United Nations Charter asserts that: "In the event of a conflict between the obligations of the Members of the United Nations under the present Charter and their obligations under any other international agreement, their obligations under the present Charter shall prevail."

${ }^{52}$ ECJ, Case 26/62, Van Gend en Loos v. Nederlandse Administratie Belastingen [1963] ECR 1.

${ }^{53}$ ECJ, Case 106/77, Amministrazione delle Finanze dello Stato v. Simmenthal SpA [1978] ECR 629.

${ }^{54}$ ECJ, Case 6/64, Flaminio Costa v ENEL [1964] ECR 585.

${ }^{55}$ ACJ Ruling 2-IP-88. See also ACJ Ruling 118-AI-2003.p.46.
} 
advocated the autonomy of the Andean legal system from that of the Member States, ${ }^{56}$ and has acknowledged the supranational nature of the Andean Community whose legal system binds both its Member States and institutions. ${ }^{57}$ Also, the ACJ has resorted to ECJ case law and European scholars to underpin the idea of autonomy of Community law against international agreements. ${ }^{58}$ The ACJ has pointed to the example of ECJ case law in Simmental and Costa $v$ Enel to highlight that the principle of supremacy developed by the ECJ is also applicable in the Andean legal order. ${ }^{59}$

The ACJ has always underscored the pivotal role of the principle of supremacy as a basis for the existence of the Andean legal order. ${ }^{60}$ The ACJ has attached considerable importance to this principle of Andean law, to the extent that it has been seen as an essential feature of community law, ${ }^{61}$ a fundamental principle ${ }^{62}$ and a requirement to the development of Andean integration. ${ }^{63}$ According to this principle, in the event of conflict between community law and national law, the former should prevail. One of the consequences of this prevalence is that the conflicting national law becomes inapplicable. ${ }^{64}$ There is, the ACJ stresses, no formal derogation of national law because both legal orders are different, separate and autonomous. However, a formal derogation may be needed for practical reasons in some cases. The ACJ underscored that the ECJ in its abovementioned landmark cases affirmed the absolute supremacy of EU law over national law. This Andean institution is convinced that this European doctrine is also applicable in the legal system of the Andean integration. ${ }^{65}$

Why did the ACJ invoke ECJ case law on this subject matter? The ACJ has made an effort to explain its recourse to ECJ case law. Prompted by the successful outcome of European integration, the ACJ employed the ECJ doctrines so as to step up Andean regional integration. In its Ruling 2-IP-90, the ACJ observed that the principle of application of community law in preference to national law, along with the principle of direct effect, contributed to the outstanding success achieved by the European integration process. In the ACJ's view, this fundamental concept makes possible the existence of a true integration law and, on these grounds, the Court asserted that it did not hesitate to endorse ECJ case law. ${ }^{66}$ Hence, the concept of prevalence of community law over national law was borrowed from the ECJ. Most relevantly, the ACJ has applied this concept to the relationship of the Andean legal order and international law, including WTO law. In this respect, the principle of supremacy defines the relationship between the Andean legal order

\footnotetext{
${ }^{56}$ ACJ Ruling 9-AI-98 and ACJ Ruling 5-IP-89.

57 ACJ Ruling 2-N-86.

${ }^{58}$ ACJ Rulings 1-IP-96.p.7 and 9.

59 ACJ Ruling 2-IP-88.p.3.

${ }^{60}$ ACJ Ruling 65-IP-2009.p.7. See also ACJ Ruling 89-IP-2009.p.6; ACJ Ruling 11-IP-2010.p.6; ACJ Ruling 12-IP-2008.p.8; ACJ Ruling 15-IP-2008.p.8.

61 ACJ Ruling 1-IP-87.p.2.

${ }^{62}$ ACJ Ruling 1-AI-97.

${ }^{63}$ ACJ Ruling 3-AI-96.

64 ACJ Ruling 12-IP-2008.p.18. See also ACJ Ruling 7-IP-99.p.16; ACJ Ruling 1-IP-87.p.2-3; ACJ Ruling 80-IP-2009.p.6; ACJ Ruling 10-IP-94.p.17; ACJ Ruling 12-IP-2008.p.18.

${ }^{65}$ ACJ Ruling 2-IP-88. See also ACJ Ruling 1-AI-97; ACJ Ruling 6-IP-93; ACJ Ruling 5-IP-89; ACJ Ruling 6-IP-93; ACJ Ruling 6-IP-94.

${ }^{66}$ ACJ Ruling 2-IP-90.p.6. See also ACJ Ruling 3-IP-94.p.4.
} 
and any other legal system, including the internal legal order of Member States and multilateral, plurilateral or bilateral agreements. ${ }^{67}$

\subsection{The supremacy of Andean law over WTO rules}

It is noteworthy that the Cartagena Agreement does not clarify the extent to which competences have been transferred to the Andean Community in the field of common commercial policy. Nor does it list, as the TFUE does, which competences belong exclusively to the Andean Community and which are shared between the Andean Community and the Member States. The Andean countries are members of other international organizations with different characteristics and objectives than those of the Andean Community but where certain areas are related to what the Andean Community covers. The WTO agreements are an outstanding case in point. Clearly, the WTO agreements govern areas that belong to the Andean Community spheres of competence. Thus, a possible allegation of collision of norms is one area of controversy that the ACJ will have to counter.

It is pertinent to note that Article 1 of Andean Decision 598 specifies that Member States can conduct preferential community or joint negotiations, and exceptionally individual negotiations for trade agreements with third countries. In such circumstances, Article 2 thereof stipulates that when community negotiations are not possible, Member States can negotiate bilaterally with third countries. In such a case, this provision calls on Member States to preserve the Andean legal order. The ACJ also ruled in favor of the Member States' obligation to preserve the Andean legal order even when they have assumed international commitments. In particular, the ACJ has stressed that the Member States' internal legal orders which encompass international norms cannot contradict or undermine Community rules. ${ }^{68}$

ACJ Ruling 1-AI-96 was the first infringement case brought to the attention of the ACJ. In that case, the ACJ held that an international obligation which is the result of international agreements to which a Member State has subscribed cannot constitute the basis for noncompliance with Andean law. Ever since, the ACJ has rejected the justification of Member States that their international agreements are a valid reason to overrule the Andean legal order. $^{69}$

More particularly, the relationship between the Andean legal order and international treaties to which Member States subscribed also explains the analysis of the ACJ. In this context, the ACJ has claimed that international law cannot override community law by relying on the transfer of powers from the Member States to the Andean Community. ${ }^{70}$ In this relationship, the ACJ has urged the supremacy of the Andean legal order over any other legal order and has affirmed that in the event of any conflict between the Andean legal order and international law, the former should prevail. The immediate effect of this supremacy of Community law is that the conflicting international norm becomes

\footnotetext{
${ }^{67}$ ACJ Ruling 115-IP-2009.p.15.

${ }^{68}$ ACJ Ruling 81-IP-2009.p.7.

${ }^{69}$ ACJ Ruling 1-AI-96.p.30.

${ }^{70}$ ACJ Ruling 1-IP-96, 07-AI-98, and 46-AI-99.
} 
inapplicable. ${ }^{71}$ For instance, the ACJ has highlighted that the Andean legal order overrides international agreements such as the General Inter-American Convention for Trade Mark and Commercial Protection adopted on February 20, 1929 at Washington D.C. ${ }^{72}$ It has also stressed that the applicable international norm must be compatible with Andean law. In essence, this assertion embraces the limitation of Member States' powers to the extent that they cannot introduce additional restrictions on the exercise of, for instance, intellectual property rights enshrined in Andean law. ${ }^{73}$

Moreover, according to ACJ case law, primary law overrides any other Community provision, namely secondary law or treaties which regulate the external relations of the Andean Community. Additionally, the ACJ asserted its jurisdiction to oversee the fulfillment of this hierarchical normative relationship. ${ }^{74}$ Thus, the Andean treaties are the cornerstone of the Andean legal order. More concretely, the ACJ has been confronted with the question of conflict between WTO and Andean law and has taken a hierarchical approach in the matter of the relationship between these two legal orders. In fact, the ACJ has responded to the cases brought before it involving the WTO agreements by applying the principle of the supremacy of Andean law. This may be explained by the fact that from the ACJ viewpoint, the existence of the Andean legal order depends on the existence of the direct applicability, direct effect and supremacy of Andean law. ${ }^{75}$

Laurence and Alter point out that,

"The ECJ has also considered the relationship between Community rules and WTO law. In contrast to the ATJ [ACJ], however, the ECJ has refused to decide whether WTO treaties trump Community rules. For example, when Germany invoked the General Agreement on Tariffs and Trade (GATT) to challenge the EC's banana imports regime, the ECJ did not resolve the compatibility of the two legal regimes." 76

They went on to add that: “...the hierarchical relationship between Community law and WTO treaties remained unresolved". ${ }^{77}$ Nevertheless, although the ACJ has explicitly declared that Andean law prevails over WTO rules, as yet, the ACJ has not assessed the compatibility of Andean law in the light of the WTO rules. Instead, as the second use patent case shows, the ACJ refuses to give an explicit response to the issue of compatibility. Indeed, the ACJ has not found that a particular WTO provision contradicts Andean law. The assessment of national or Community measures made by the ACJ was undertaken under Community law. Therefore, the approach taken by the ECJ in refusing to deal with the compatibility of EU law and WTO rules is similar to that of the ACJ. Moreover, the ACJ's standpoint differs from that of the ECJ as regards the manner in which both judicial bodies face the question of the relationship between Community law and WTO provisions.

\footnotetext{
71 ACJ Ruling 15-IP-2008. See also ACJ Ruling 6-IP-94.p.24; ACJ Ruling 36-IP-2009.p.18; ACJ Ruling 65IP-2009.p.12; ACJ Ruling 11-IP-2010.p.7; ACJ Ruling 217-IP-2005.p.7.

${ }^{72}$ ACJ Ruling 36-IP-2009.p.6.

73 ACJ Ruling 36-IP-2009.p.18.

${ }^{74}$ ACJ Ruling 1-IP-96.

${ }^{75}$ ACJ Ruling 118-AI-2003.p. 44

${ }^{76}$ Laurence R. Helfer \& Karen J. Alter. Legal Integration in the Andes: Law-Making by the Andean Tribunal of Justice, 17 European Law Journal, 2011.p.714.

${ }^{77}$ Laurence R. Helfer \& Karen J. Alter. Op.cit.p.714.
} 
While the ECJ addressed primarily the issue of direct effect, and on this basis it rejects a review of the legality of EU law vis-à-vis WTO, the ACJ has always coped with this question by first declaring the supremacy of Andean law and in many instances leaving untouched the issue of direct effect in the same way the ECJ did.

The ACJ accepts that states have a responsibility if they fail to comply with international norms. It does not deny the competence of the WTO dispute settlement system but it will not accept that the application of Andean law be conditioned upon its compatibility with WTO rules.

\subsection{The allegation of compliance with WTO rules by Andean Member States: a WTO exemption for their obligations?}

Member States have attempted to implement national laws which were in conflict with Andean legislation on the grounds that they were issued to comply with WTO rules. No conflict of WTO and Andean law has been discussed in these cases. The question has rather been about the compatibility of a national measure with Andean law, with one Member State defending such a measure in the light of WTO law. The ACJ has not accepted a WTO exemption in the fulfillment of the obligations of Member States assumed within the Andean Community. ${ }^{78}$ When Member States argued before the ACJ that they are bound to adopt WTO agreements, the ACJ replied with its jurisprudence on the hierarchical position of Andean law. ${ }^{79}$

Ecuador made the case that its Resolution 183 of COMEXI was based on the Agreement on Import Licensing Procedures of the WTO and that its procedures cannot be considered a restriction on trade, being consistent with Andean and national law. The ACJ responded to this argument by making a statement of principle regarding the relationship between Andean states with both Andean and WTO law. In the ACJ's view, the participation of Andean states in the WTO does not exempt them from the obligation to abide by Andean law. The fulfillment of WTO law cannot be used as an excuse to violate Andean law. According to the ACJ, allowing such a violation amounts to the denial of the supremacy of the Andean legal order. The ACJ pointed out that the Andean legal order prevails over the national legal order of the Member States and any other international legal order to which they belong. In this connection, the ACJ stated the reasoning in its own jurisprudence about the nature of the principle of supremacy in Community law. It not only rejected Ecuador's argument but also argued that it was important that the internal rules of the Member States should not be contrary to the Andean legal order and its underlying principles for the normal development and evolution of the Andean subregional integration process. ${ }^{80}$

The need to foster Andean integration appears to be decisive for the assessment of the Court. The approach taken in this case reflects the ACJ's concern over the Andean integration process when Member States sign international agreements. In essence, the affirmation of the supremacy of Andean law over WTO rules is an instrument to ensure that

\footnotetext{
${ }^{78}$ ACJ Ruling 10-AN-200 and 61-AN-2000 (joint).p.25-26.

${ }^{79}$ ACJ Ruling 43-AI-2000.p.24-25.

80 ACJ Ruling 117-AI-2003.p.18. See also ACJ Ruling 217-IP-2005.p.7-8; ACJ Ruling 10-AN-2000.p.26; ACJ Ruling 43-AI-2000.p.24-25; ACJ Ruling 136-AI-2004.
} 
such integration is not being undermined. The ACJ is aware that states may prefer to apply WTO rules if those rules favor their interests. Being aware of this, in order to prevent states from choosing the more favorable law, the ACJ declares that Andean law must be given preference in its application in all cases. In fact, the principle of supremacy is utilized in cases where the ACJ wants to promote the fulfillment of Andean law.

In a similar case, Member States have also invoked their rights derived from the WTO agreements to justify their national measures before the ACJ. For instance, Ecuador tried to justify some restrictions on imports imposed on soybean meal, referring to the Agreement on the Application of Sanitary and Phytosanitary Measures of the WTO (SPS Agreement) and Andean Decision 328. Ecuador argued that as a WTO member it applied the SPS Agreement which recognized the right to WTO members "to take sanitary and phytosanitary measures necessary for the protection of human, animal or plant life or health". ${ }^{81}$ Interestingly, the ACJ disregarded the question of the enforceability of WTO rules in the Andean Community and declared Ecuador had infringed Andean law.

In another case, the ACJ noted that Colombia had invoked WTO law as a defense for the utilization of safeguard measures. The ACJ followed a different approach from that in the foregoing case and responded to the allegation of Colombia with reference to the supremacy of Andean law. ${ }^{82}$ Interestingly, the ACJ did declare any inconsistency between WTO and Andean law. Indeed, such compatibility was not ascertained. Nevertheless, the ACJ rejected the argument of Colombia that WTO law was the applicable law and reproduced its case law concerning the supremacy of Andean law over WTO law. Furthermore, it took the view that in the event of finding legal loopholes in the Andean legal order, the general principles of Community law, substantive laws of the Member States, and the principles of international law could be used. ${ }^{83}$

Another noteworthy case is related to the unilateral modification of the Andean Common External Tariff undertaken by Ecuador to impose higher tariffs. When the matter was submitted to the ACJ, Ecuador attempted to justify this measure by arguing that such a measure was consistent with the bound commitments on customs duty rates taken up by this Andean country in the WTO. ${ }^{84}$ The ACJ noted that pursuant to Article 86 of the Cartagena Agreement (the then Article 98) Member States shall carry out consultations within the Andean Commission before assuming tariff obligations with countries outside the Andean Community. ${ }^{85}$ In such circumstances, the alleged compatibility of such modification with WTO provisions did not persuade the ACJ which was unequivocal in stating that the commitments assumed in the Andean context prevail over any other international commitment. ${ }^{86}$

\footnotetext{
${ }^{81}$ ACJ Ruling 28-AI-2001.p.4, 9.

${ }^{82}$ ACJ Ruling 118-AI-2003.p.43-46.

83 ACJ Ruling 118-AI-2003.p.47. Some Andean countries have also expressed their support for the application of WTO agreements in the Andean Community if there is a gap in the Andean legislation. See ACJ Ruling 118-AI-2003.p.25.

${ }^{84}$ ACJ Ruling 7-AI-98.p. 17.

${ }^{85}$ ACJ Ruling 7-AI-98.p. 18.

${ }^{86}$ ACJ Ruling 7-AI-98.p. 19.
} 
The fact that Andean countries are invoking their rights accorded by the WTO agreements before the ACJ indicates that they do not clearly understand the position of WTO law in the Andean legal order. Any commitment made by the Member States in their external relations should not impinge on the Andean Community system.

\subsection{Member States' infringement of WTO rules and the role of the Andean institutions}

In many, if not most, cases the ACJ took the same approach in preliminary rulings proceedings where in the internal procedure held before a domestic court the application of international agreements, such as the Paris Convention and WTO agreements, was discussed. The hierarchical relationship between Andean and WTO law and the lack of direct effect of the latter will always be stressed. ${ }^{87}$ For instance, the question concerning the possible violation of WTO rules by domestic legislation surfaced in a case relating to the application of the General Agreement on Trade in Services (GATS Agreement). In a foreign investment case involving a contract between private parties held in an Ecuadorian court, the defendant went to the national court to question the legality of the national law (Supreme Decree 1038-A of Ecuador) against Article 27 of the GATS Agreement. The defendant argued that this international agreement should be applied as it prevailed over domestic law. ${ }^{88}$ The national court referred the case to the ACJ through preliminary ruling proceedings and the ACJ made an interpretation of the provisions of Andean Decision 291 which regulated foreign investment. The ACJ used this occasion to repeat its case law on the supremacy of Andean law and reiterated the lack of direct effect of WTO rules. Moreover, the ACJ instructed the national court to apply this concept when ruling on the case.

Some observations are called for relating to the last point stressed by the ACJ. Why does a national judge have to take into account the jurisprudence of the ACJ denying direct effect to WTO law? Can the ACJ decide about the direct effect of WTO rules in the national legal order of the Member States? WTO law lacks direct effect in the Andean Community but the ACJ cannot decide about the legal effect of international agreements signed by the Member States. In other words, the denial of direct effect to WTO law made by the ACJ within the Andean context cannot be transmitted to the internal legal order of the Member States.

Interestingly, in the abovementioned case, the defendant did not question the legality of Andean rules in the light of the GATS Agreement but rather the compatibility between national law and the GATS Agreement. Why did the ACJ recall the supremacy of Andean rules over WTO law and the lack of direct effect? It seems that the ACJ wanted to secure the application of Andean law. It is noteworthy in this regard that the ACJ is forbidden to interpret the national law of Member States in preliminary ruling proceedings. ${ }^{89}$ It is worth noting that the ACJ has clarified that international agreements or treaties signed by the Member States are within the scope of what is characterized as the Member States' internal

\footnotetext{
${ }^{87}$ ACJ Ruling 224-IP-2005.p.18-19; ACJ Ruling 18-IP-2006.p.27; ACJ Ruling 71-IP-2006.p.19; ACJ Ruling 106-IP-2006.p.18; ACJ Ruling 107-IP-2006.p.18; ACJ Ruling 59-IP-2006.p.17; ACJ Ruling 192-IP-2006.p.56; ACJ Ruling 117-IP-2007.p.20-21.

${ }^{88}$ ACJ Ruling 158-IP-2006.p.5.

${ }^{89}$ Article 34 of the Treaty Establishing the Andean Court of Justice.
} 
legal orders. ${ }^{90}$ Since international agreements signed by Member States are part of their internal legal system, the ACJ does not have competence to interpret those agreements. This argument was also raised by the Constitutional Court of Colombia in its referral made to the ACJ in a preliminary ruling procedure. ${ }^{91}$ Therefore, the ACJ interpreted Decision 291 and had to leave it up to the national court to define whether this was an issue of foreign investment treatment or fulfillment or nonfulfillment of a distribution contract of foreign products negotiated in Colombia. ${ }^{92}$

In sum, it is worth recalling that it is not the mandate of the ACJ to oversee the fulfillment of Member States' international obligations such as those within the WTO. In addition, Andean legislation does not mandate Member States to comply with international agreements they have individually signed. Neither can the ACJ instruct the national courts to interpret national law in conformity with WTO law in preliminary ruling proceedings, unless the Andean Community has incorporated a WTO provision and such provision has therefore become part of the Andean legal order. Furthermore, the legal effect of such international agreements in the national legal order must be decided by the Member States and not the ACJ. Therefore, the fact that the ACJ underscored the lack of direct effect of WTO in this preliminary ruling where the legality of Andean law was not questioned against WTO law may lead to confusion. That is because a national norm was assessed against WTO law, and the ACJ cannot constrain the right of Member States to decide about the effect of their international agreements in their national legal order. Granted that one Andean country decides to grant direct effect to WTO law, the only competence of the ACJ would be to foresee that Andean law is respected in a case taken up with the Court.

This case illustrates that the ACJ has availed itself of all the opportunities to underline the supremacy of Andean law over international agreements signed by the Andean states, in particular the WTO agreements. This case reflects that the declaration of supremacy of Andean law by the ACJ was more a rhetorical affirmation of the need to reinforce the recognition of the Andean legal system. From the ACJ viewpoint, it is clear that Andean law must be applied, regardless of the obligations of the Andean Members in other fora such as the WTO. It is submitted that the ACJ has endorsed a conservative and defensive approach to applying Andean law, perhaps in view of the Member States' possible breaches of Andean law in order to follow WTO law. The functioning of the Andean integration process has been central to the ACJ's approach.

\section{Understanding the Andean Court of Justice case law}

The review of ACJ case law reveals some unresolved issues as regards the manner in which the ACJ framed the relationship between Andean and international law. The first consideration is that, in the abovementioned second use patent cases, when the enforcement of a WTO agreement was requested, it is submitted that the ACJ did not take into consideration that supremacy cannot be declared unless an inconsistency has been found between Andean and WTO law. As mentioned earlier, the ACJ has settled that this principle is applied in the event of conflict between Andean law and international treaties

\footnotetext{
${ }^{90}$ ACJ Ruling 81-IP-2009.p.6.

91 ACJ Ruling 1-IP-96.

${ }^{92}$ ACJ Ruling 158-IP-2006.
} 
signed by the Member States. However, no inconsistencies were found between these two legal orders as they were not even subject to review in the given case. Therefore, the case should not have been addressed on the basis of the application of the principle of supremacy articulated by the ACJ to analyze the relationship between Community and national law. It is submitted that it suffices to declare that the WTO cannot have direct effect in the Andean Community, and therefore a measure adopted by an Andean institution cannot be reviewed vis-à-vis WTO law. The consequence of not addressing the issue of direct effect clearly can be seen in the Resolution adopted by the General Secretariat in the Peru antidumping case discussed below.

The second consideration is that a different approach was adopted by the ACJ in other cases concerning the comparison between an international agreement and Andean law. The most noteworthy example is ACJ Ruling 1-IP-96. In one such case, the ACJ analyzed for the first time two different legal systems and determined the relationship between community law represented by the Cartagena Agreement and the law derived from an international agreement such as the Paris Convention for the Protection of Industrial Property (Paris Convention). The Constitutional Court of Colombia requested the ACJ to express its position as to whether the concept of patent of the Paris Convention contravened the Cartagena Agreement. This Constitutional Court pointed out that the ACJ lacked competence to interpret the international treaties signed by the Andean states but requested the interpretation of former Decision 344 and Decision 345 in order to identify a potential conflict with the Paris Convention.

In its Ruling 1-IP-96, the ACJ held that the international agreements subscribed to by the Andean countries in areas such as intellectual property, where the Andean members have conceded competence to the Community, are linked to the Community, namely that such international agreements serve as a framework under which the Andean Community operates to develop its regulatory activity. However, the ACJ clarified that community law is not subordinated to such international agreements. The recognition of international law as a source of law for community law does not imply that the Andean Community is obliged by it. The ACJ stated that international agreements are part of the applicable legal order in each and every Andean country but community law should continue to take preference over the national legal order of Member States. ${ }^{93}$ More importantly, the contrast with the reasoning in the second use patent cases is worth observing. The ACJ asserted that it was necessary to refer to the Paris Convention and that a comparison should be made between Article 1 numeral 3 of the international agreement and Articles 1 through 7 of the former Andean Decision 344. After reviewing both legal systems, the ACJ concluded that there was no incompatibility between Articles 6 and 7 of the former Andean Decision 344 and the Paris Convention. In addition, the ACJ concluded that there was no incompatibility between Article 28 of the Paris Convention and Article 33 of the Treaty Establishing the Andean Court of Justice. With respect to the core idea, the ACJ emphasized that it had engaged in a review of Community law in order to determine the compatibility or lack thereof of the Andean Decisions with the Paris Convention. ${ }^{94}$ Another interesting point is

\footnotetext{
${ }^{93}$ ACJ Ruling 1-IP-96.p.9. See also ACJ Ruling 43-AI-2000.p.24-25.

${ }^{94}$ ACJ Ruling 1-IP-96.p.11, and 16.
} 
that the ACJ considered that it was important to refer to the nature and characteristics of the Paris Convention. ${ }^{95}$

In the wake of these diverging ACJ decisions, the question that remains open is why the ACJ is willing to assess and declare the compatibility between the Paris Convention and Andean law but unwilling to make such an assessment and declaration in the case of the WTO agreements. The question can be posed thus: why is it inappropriate to compare the Andean and WTO legal orders but not the others? The ACJ has not provided the underlying reason for creating this distinction. In fact, no distinction has been drawn with regards to the nature of an international agreement such as the Paris Convention and the WTO Agreement to justify this differentiation. Looking at both treaties through the lens of international law, there is no room for distinction.

There are various explanations for the different approaches of the ACJ in these cases. Looking at the nature of the legal actions involving WTO rules, it is possible to make the following observations. First, in infringement procedures, when Community law is challenged against WTO provisions and the application of the latter is demanded, the ACJ seems to be more defensive and protective of the Andean legal order. In these cases, the ACJ not only refuses to compare the Andean provision with WTO law but also immediately affirms that Andean law prevails over WTO law without finding any conflict. In fact, this reluctance to compare both legal systems marked a substantial shift in the manner in which the ACJ approached the relationship between Community law and international agreements signed by Member States, such as the Paris Convention. Second, in preliminary rulings proceedings, when Andean legislation is not jeopardized, the ACJ may be more open to engage in assessing whether international agreements contradict or agree with Andean laws. Consequently, so long as the full application of the Andean norms is not set aside, the ACJ will interpret and compare Andean law in the light of international agreements. Preliminary rulings proceedings presumably give the Court more leeway when assessing the compatibility between Andean and international law. However, these observations are pertinent as they reveal much about the reaction of the ACJ to the WTO membership of Andean Community Member States in the light of the Andean rules.

The question remains as to whether the ACJ will take the same approach adopted in Ruling 1-IP-96 with specific regard to the WTO norms following a referral by a national court. What would have happened if the ACJ had considered that the Paris Convention was incompatible with the provisions of the Cartagena Agreement? The Member States of the Andean Community must observe their commitments under the Andean legal system. In application of the principle of cooperation enshrined in the Treaty Establishing the Andean Court of Justice, ${ }^{96}$ they should adopt all the necessary measures to give life to Andean law and should refrain from adopting those measures that may jeopardize Community law.

\footnotetext{
${ }^{95}$ ACJ Ruling 1-IP-96.p.10.

96 Article 4 reads as follows: "Member Countries are under the obligation to take such measures as may be necessary to ensure compliance with the provisions comprising the legal system of the Andean Community. They further agree to refrain from adopting or employing any such measure as may be contrary to those provisions or that may in any way restrict their application.”
} 
One the basis of the foregoing remarks, it is possible to argue that the analysis conducted by the ACJ reflects that this Court adopts a stricter and tougher approach when WTO rules are invoked.

More to the point, in its Ruling 114-AI-2004 the ACJ addressed the relationship between the Andean Decision 486 and the TRIPS Agreement and held that Decision 486 is in harmony with the TRIPS Agreement. More specifically, the ACJ compared Article 266 of Andean Decision 486 with Article 39.3 of the TRIPS Agreement and noted the similarities and differences between both Articles. ${ }^{97}$

\section{The doctrine of consistent interpretation in the Andean Community}

\subsection{The Andean Court of Justice and consistent interpretation}

The ACJ has shown its preference for the utilization of the doctrine of consistent interpretation and maintained that, whenever possible and necessary, community law should be interpreted in conformity with international agreements, in particular if international law has been the source of community law. The ACJ has recognized the usefulness of the concepts and categories of international law to clarify community law, in particular whenever some ambiguous or blurred terms are found. It also shows its preference, whenever possible, for compatible interpretation of these two rules, in particular if the international norm has been a source of community law. ${ }^{98}$ It should be noted that the ECJ has also followed the consistent interpretation approach. The ECJ has held that: “...it should be recalled that Community legislation must, so far as possible, be interpreted in a manner that is consistent with international law, in particular where its provisions are intended specifically to give effect to an international agreement concluded by the Community..."99 The analysis conducted by the ACJ has been influenced by the ECJ. To clarify this point, a review of ACJ case law is illustrative. In effect, as regards the methods of interpretation which the ACJ should use, the Andean Court has maintained that regard should be paid to the important contribution of ECJ case law which is being constantly developed for the benefit of community construction without disregard for the objective of the law. ${ }^{100}$ Thus, it is fair to say that the ACJ, which has long looked to the decisions of ECJ case law for guidance, has adopted the doctrine of consistent interpretation following ECJ case law.

In respect of the scope of the doctrine of consistent interpretation, Cottier and Nadakavukaren Schefer point out that, "where a national rule allows for different interpretations, national or regional law has to be construed in accordance with international obligations. In many instances, conformity in interpretation allows bridging alleged divergences between international, national or regional law, making adherence to both a treaty and national law possible." ${ }^{101}$ In addition, Bronckers observes that "as long as

\footnotetext{
${ }^{97}$ ACJ Ruling 114-AI-2004.p.36.

${ }^{98}$ ACJ Ruling 35-AN-2003.p.29.

${ }^{99}$ ECJ Case C 76/00, Judgment of 9 January 2003.para.57.

${ }^{100}$ ACJ Ruling2-AI-96.p.50.

${ }^{101}$ Cottier and Nadakavukaren Schefer note that: "Except where WTO rules have direct effect, national and regional courts do not primarily rely on the WTO in decision-making." Cottier, Thomas and Nadakavukaren
} 
a private litigant does not challenge the legality of EC measures on the basis of WTO law, the European courts show themselves quite willing to interpret EC (or, for that matter, national) measures as much as possible in conformity with WTO law". ${ }^{102}$ Initially, the Andean institutions tried to follow this conceptual framework and have shown their willingness to make this type of consistent interpretation; however, as discussed below, they have not always been clear in drawing the line between consistent interpretation and making WTO rules directly applicable.

\subsection{Drawing the line between enforcement of WTO rules and consistent interpretation}

The General Secretariat lodged a complaint against Colombia alleging the violation of the principle of national treatment enshrined in Article 75 (ex-Article 74) of the Cartagena Agreement. In such a case, the ACJ accepted the application of a GATT provision. Article 75 of the Cartagena Agreement prescribes that "Products originating in a Member Country shall enjoy, in the territory of another Member Country, treatment that is no less favorable than that accorded to similar domestic products, insofar as taxes, assessments and other domestic duties are concerned". The General Secretariat referred to the GATT and argued that products originating in the Andean Community should not only enjoy national treatment as regards taxes, assessments and other domestic duties but also laws, regulations and requirements affecting the internal sale, offering for sale, purchase, transportation, distribution or use of products according to the language of the GATT. ${ }^{103}$

The ACJ reviewed how the principle of national treatment has been enshrined in other international treaties signed by the Andean countries, such as the WTO agreements. First, it observed that Colombia is a WTO member as are all the Andean countries. Second, it cited Article III of the GATT and argued that products originating in the Andean Community should not only enjoy national treatment as regards taxes, assessments and other domestic duties but also as regards laws, regulations and requirements affecting the internal sale, offering for sale, purchase, transportation, distribution or use of products pursuant to the language of the GATT, along with the Free Trade Agreement signed between Colombia, Venezuela and Mexico, also known as the Group of Three Accord. ${ }^{104}$ Thus, the ACJ fully endorsed the General Secretariat's argument on this point. It is noteworthy in this regard that Article 3-03 of the Group of Three Accord fully incorporated Article III of the GATT. It is fair to say that the ACJ stressed the WTO membership of the Andean countries as grounds to justify its reference to the GATT, considering that the multilateral agreement was legally binding for them.

Three other points are noteworthy in this regard. First, a comparison of Article 75 of the Cartagena Agreement together with Article III of the GATT reveals that the latter is broader in scope. Clearly, it is for this reason that the ACJ showed its preference for using

Schefer, Krista. The Relationship between World Trade Organization Law, National and Regional Law. Journal of International Economic Law, 1 (1), 1998.p.88.

${ }^{102}$ Bronckers, Marco. From 'Direct Effect' to 'Muted Dialogue': Recent Developments in the European Courts' Case Law on the WTO and Beyond. Journal of International Economic Law 11(4), 2008. p.888.

${ }^{103}$ ACJ Ruling 3-AI-97.p.5.

${ }^{104}$ ACJ Ruling 3-AI-97.p.22. 
the GATT language. The ACJ reiterated its opinion in subsequent rulings. ${ }^{105}$ Second, the ACJ did not examine whether the General Secretariat had the right to rely on the GATT before the ACJ. Third, the ACJ did not assert the need for consistent interpretation to ensure that Article 75 of the Cartagena Agreement was interpreted in conformity with Article III of the GATT. In fact, the ACJ did not even mention that Article III of the GATT had been taken into account as a supplementary source of law or used to fill in the gap in the principle of non-discrimination under Andean law. Neither did the ACJ refer to any principle of international law in its reasoning. Most prominently, the ACJ did not invoke the 1969 Vienna Convention on the Law of Treaties when applying the language of the GATT. Instead, it stressed at the outset that Colombia was a WTO member. This approach differs from that adopted by the ACJ in other cases. As indicated above, the ACJ resorted to the TRIPS Agreement in its Ruling 2-AI-96. However, in that case, before embarking upon its interpretation dealing with the principle of free movement of goods and the protection of intellectual property rights as a possible exception to such a principle, the ACJ ruled out the possibility of applying ECJ case law in the case at hand. The ACJ explained its decision as resulting from the fact that Article 36 TFEU encompasses the protection of industrial and commercial property as grounds for justifying the introduction of restrictions on imports. By contrast, in the Andean Community, the protection of industrial and commercial property as an exception to the free movement of goods is not spelled out in the Cartagena Agreement but rather in secondary legislation. After acknowledging this difference concerning the legal source of this exception to the free movement of goods, the ACJ asserted that European jurisprudence and doctrine cannot be fully applicable to the Andean case. ${ }^{106}$ After this finding, the ACJ construed the relevant Andean provisions and highlighted that in support of its interpretation it had resorted to international agreements signed by the Member States because these had been considered as sources of law by the ACJ itself. ${ }^{107}$ The order of assessment employed to interpret Andean law suggests that the ACJ would first resort to the ECJ case law and only when such case law cannot be applied, will it use the international treaties signed by the Member States, such as the WTO agreements.

More to the point, in the abovementioned case against Colombia, the ACJ did not carry out any interpretation of Article 75 of the Cartagena Agreement in the light of Article III of the GATT to avoid a norm collision or to clarify the Andean provision. It should be noted that it was not the compatibility of the Andean provision with the GATT that was questioned in the case but rather the infringement of Andean law by Colombia. Perhaps this is the reason why the ACJ felt more comfortable with citing the GATT and directly applying it to the facts of the case. The wording of the ACJ rulings reflects that the ACJ employed Article III of the GATT as part of the basis for its decision. ${ }^{108}$ Cottier and Nadakavukaren Schefer note that: "Except where WTO rules have direct effect, national and regional courts do not primarily rely on the WTO in decision-making." ${ }^{109}$ By adopting this approach, in this particular case, the ACJ departs from the general approach followed by other courts when dealing with WTO rules. Marceau, Izaguerri and Lanovoy found that "the jurisdiction that

\footnotetext{
105 ACJ Ruling 132-AI-2003.p.19. See also ACJ Ruling134-AI-2003.p.12.

${ }^{106}$ ACJ Ruling 2-AI-96.p.32.

${ }^{107}$ ACJ Ruling 2-AI-96.p.34.

${ }^{108}$ Cottier, Thomas and Nadakavukaren Schefer, Krista. Op.cit.p.86-87.

${ }^{109}$ Ibid.p.86.87.
} 
most referenced the WTO, the Andean Court of Justice, is also the one that most rejected its applicability." 110 In fact, three years after this judgment was rendered, the ACJ adopted a more defensive position in the so-called Viagra case on second use patents when the legality of Andean rules was questioned vis-à-vis WTO law. It is noteworthy that the attitude of the ACJ in borrowing concepts introduced in other international agreements is not new. ${ }^{111}$

Marceau, Izaguerri and Lanovoy observe: "whereas the WIPO tribunal seems to consider itself to be bound to WTO case law, the Andean Court seems determined to distance itself from it."112 In this respect, for example, the ACJ has the tendency to resort to ECJ case law even when citing or referring to WTO agreements. In this case, albeit the ACJ employed Article III of the GATT, it resorted to the ECJ case law concerning the conceptual scope of the principle of non-discrimination, among other factors. ${ }^{113}$

\subsection{The approach of the General Secretariat towards the application and status of WTO rules}

With a view to ensuring that WTO obligations are met by the Member States, the General Secretariat also opted for the doctrine of consistent interpretation. However, the manner in which the Andean institution applied this principle merits some observations. The General Secretariat has held that when facing a set of legally acceptable interpretations, the interpretation chosen must be compatible with the obligations of a state, or in this case, the obligations of the Andean states. In its view, by using this technique it is possible to preserve the principle of pacta sunt servanda, facilitate the fulfillment of those international obligations in good faith and avoid international responsibility. The General Secretariat finds this technique to be useful in particular when there is a need to compare national, regional or international legal systems and avoid, whenever possible, the contradictions between state obligations. The General Secretariat takes the view that if an Andean rule allows its application, which is compatible with the WTO provision without jeopardizing its content and scope, the interpreter must choose this solution. It added that any potential conflict between an Andean norm and a WTO provision cannot be settled through consistent interpretation. ${ }^{114}$ Despite these considerations and the assertion of the scope of the doctrine of consistent interpretation, the General Secretariat erred in the utilization of this concept, as shown by the cases discussed below.

\footnotetext{
${ }^{110}$ Marceau, Gabrielle, Izaguerri, Arnau and Lanovoy, Vladyslav. The WTO’s Influence on Other Dispute Settlement Mechanisms: A Lighthouse in the Storm of Fragmentation. Journal of World Trade, 47 (3), 2013.p.531.

111 Concerning the application of the concept of measures having equivalent to quantitative restrictions of Article 34 of the TFEU to the interpretation of the Cartagena Agreement see, Reyes Tagle, Yovana. Free Movement of Goods in the Andean Community: How far can Dassonville go? SECO/WTI Academic Cooperation Project Working Paper Series Available http://www.wti.org/fileadmin/user_upload/wti.org/7_SECOWTI_Project/Publications/Reyes\%20Tagle\%20FMG\%20dic\%202012.pdf.

112 Marceau, Gabrielle, Izaguerri, Arnau and Lanovoy, Vladyslav.Op.cit.p.528.

113 ACJ Ruling 3-AI-97.p.20, 23, 26-27, 29.

${ }^{114}$ ACJ Ruling 35-AN-2003.p.7.
} 
A review of the Resolutions of the General Secretariat reveals that this community institution referred to and took into consideration WTO agreements in its decisions, and in some cases, attempted to enforce WTO law in the Andean legal order.

In the second use patents case, Pfizer argued before the General Secretariat during the administrative stage of the infringement procedure that a prohibition on the granting of second use patents in light of the former Andean Decision 344 breached Articles 27.1 and 70.2 of the TRIPS agreement. In Pfizer's view, this infringement would give rise to a procedure in the framework of the WTO dispute settlement system against the Andean Community members. The General Secretariat responded to this argument by stating that the TRIPS Agreement did not deal with the competence of WTO members to accept the patentability of second use patents. Moreover, this community institution reasoned that the TRIPS Agreement does not oblige WTO members to patent second uses. It stated that the multilateral agreement did not mention second use patents and rejected the argument raised by Pfizer that there was an infringement of multilateral rules. The General Secretariat engaged in an interpretation of Article 27 and other Articles of the TRIPS Agreement as regards second used patents. ${ }^{115}$ In other words, the General Secretariat showed its willingness to embark upon the TRIPS Agreement analysis when an Andean provision was challenged against WTO law, and took the additional step of concluding that the former Andean Decision 344 was not WTO-inconsistent. Besides, the General Secretariat recalled the jurisprudence of the ACJ that Andean law prevailed over international agreements, although it came to the conclusion that there was no incompatibility. One important point to bear in mind is that this approach substantially differed from that of the ACJ. In sharp contrast to the General Secretariat's approach, the ACJ did not review such compatibility or how the TRIPS Agreement treated second use patents, instead limiting itself to declaring the supremacy of Andean law.

Likewise, the question of the status of WTO rules within the Andean legal order was discussed by the General Secretariat and the ACJ in another case. In the Peru antidumping case, a controversy arose concerning whether the General Secretariat had the competence to interpret the Andean legal order in the light of the obligations of Andean states in the WTO and the possibility that such interpretation amounts to a lack of recognition of the supremacy of community law. Two positions were adopted by the Andean institutions. Notably, during the administrative stage, the General Secretariat demanded the applicability and respect of WTO law by Andean states. This community institution considered that the Andean states are also WTO members and have assumed obligations to apply antidumping measures in accordance with the Agreement on Implementation of Article VI of the General Agreement on Tariffs and Trade 1994 (Antidumping Agreement). For this reason, it argued that it took into account the Antidumping Agreement in a supplementary manner so long as incompatibility with the Andean antidumping rules did not exist. ${ }^{116}$ In this sense, it held that in accordance with Article 14.4 of the Antidumping Agreement, the establishment of antidumping measures was subject to and depended on the approval of the WTO Council for Trade in Goods. As a consequence thereof, the General Secretariat, taking into account Article VI.6.b) of the GATT and Article 14 of the Antidumping Agreement, issued its Resolution and imposed on Peru the obligation to notify such

${ }^{115}$ General Secretariat Resolution 476.

${ }^{116}$ General Secretariat Resolution 672. 
Resolution and report to the WTO in order to comply with WTO rules. Furthermore, this executive organ went even further to demand that the antidumping measures be enforced and applied by Peru immediately after such approval. ${ }^{117}$

During the judicial stage, the General Secretariat went so far as to claim that the antidumping investigation was conducted consistently with WTO requirements and justified the requirement of notification of its Resolution 672 to the WTO in order to avoid any possible difficulty in the WTO. ${ }^{118}$ The concern of the General Secretariat over the possible deviation of Andean law from the WTO provisions was clear.

On the other hand, against the allegations of Member States or private parties that the General Secretariat's decisions were contrary to the Andean states' obligations in the WTO, this institution not only responded with the ACJ case law affirming the supremacy of Andean rules but rather it again decided to analyze the WTO Agreement to conclude that such violation did not exist. ${ }^{119}$ Interestingly, the General Secretariat did not observe that the Andean decision cannot illegally breach WTO law because the Andean Community is not a WTO member. Instead, it engaged in the analysis of compatibility. On balance, any Andean decision approved by its institutions which is contrary to the WTO agreements will affect the manner in which the Andean members will abide by their multilateral obligations but the responsibility is exclusively for the Andean states.

In sharp contrast, the ACJ opted for the preferential application of Andean law and specified that such law has to be applied in preference to other legal order by its institutions. The ACJ disagreed with the General Secretariat and correctly stated that WTO law did not form an integral part of the Andean Community legal order. In effect, it concluded that the Andean institutions are not bound to oversee the fulfillment of the multilateral rules. Also, the ACJ considered that the obligations imposed on Peru by the General Secretariat are not part of the commitments of Member States within the framework of the Andean Community and hence cannot be demanded by such an institution. The ACJ recalled Article 1 of the Treaty Creating the Andean Court of Justice to underline that the WTO agreements are neither primary nor secondary law in the Andean Community. $^{120}$

It should be noted that Article 1 of the Treaty Creating the Andean Court of Justice, as amended by the Cochabamba Protocol, prescribes that the juridical system of the Andean Community is made up of: the Agreement of Cartagena, its Protocols and Additional Instruments; the Treaty Creating the Court of Justice of the Andean Community and its Amending Protocols; the Decisions of the Andean Council of Foreign Ministers and of the Commission of the Andean Community; the Resolutions of the General Secretariat of the Andean Community; the Industrial Complementarity Agreements and any others the Member Countries may adopt among themselves and within the framework of the Andean subregional integration process. The legal instruments approved by the institutions of the Andean Community have special legal effects. Article 3 of the Treaty Creating the Andean

\footnotetext{
${ }^{117}$ Articles 2 and 3 of the General Secretariat Resolution 672.

118 ACJ Ruling 35-AN-2003.p.27.

${ }^{119}$ General Secretariat Resolution 618.

${ }^{120}$ ACJ Ruling 35-AN-2003.p.29-30.
} 
Court of Justice holds that the decisions adopted by the Andean Council of Ministers of Foreign Affairs or the Commission are binding for all Member Countries and are directly applicable.

Furthermore, the ACJ does not deny the possibility to interpret community law in the light of international norms. However, it rejects the possibility that such an international norm could replace community law and be applied instead. ${ }^{121}$ As to the arguments of the General Secretariat concerning the compliance with WTO provisions by Member States, the ACJ noted that in accordance with Article 30 a) of the Cartagena Agreement the primary function of the General Secretariat as a community institution was to oversee the fulfillment of the Andean legal order. As such, the ACJ questioned the decision of this institution which was more concerned with the application of WTO rules, in particular the Antidumping Agreement. The ACJ stated that making the application of community law conditional upon the fulfillment of WTO rules by Andean states amounted to the suspension of the application of community law. In the ACJ's view, the General Secretariat Resolution violated two important principles of the Andean legal order: direct applicability and direct effect. Based on these findings, the court declared this part of the Resolution of the General Secretariat void. ${ }^{122}$ The key difference between the General Secretariat's decision and the ACJ's lies in how they interpret their competences as Andean institutions.

The General Secretariat attempted to understand the situation of the participation of Member States of the Andean Community in the WTO and reacted with what it termed consistent interpretation of the Andean rules in the light of the obligations of the Andean states in the WTO. ${ }^{123}$ Nonetheless, such a consistent interpretation cannot be extended to include the possibility to demand Andean states comply with WTO law before applying Andean law, as the General Secretariat did in the Peru antidumping case. Requirements that are not set down in the Andean rules should not be incorporated through consistent interpretation with the WTO rules. It is evident that it is not the task of the Andean Community.

What is the standard of review that the ACJ can use to assess the legality of measures adopted by the Andean institutions or the Member States? Article 4 of the Statute of the Andean Court of Justice provides the legal basis for the standard of review of the ACJ. According to this Statute, the ACJ shall ensure the uniform application and interpretation of Andean law in all Member States. Member States can negotiate in order to bring Andean law into conformity with WTO rules through the Andean mechanisms. As pointed out below, this is in fact what they have done since the establishment of the WTO. Indeed, noncompliance with WTO obligations cannot be sanctioned by the ACJ. Additionally, the ACJ is not called upon to analyze and declare whether Andean law is consistent with the rules set out in the WTO agreements. The ACJ lacks jurisdiction to assess the validity of an Andean act in the light of WTO law. In an annulment action, for instance, an act of the Andean institutions can only be declared void by the ACJ if such act is inconsistent with the norms that are part of the Andean legal order. ${ }^{124}$ Clearly, the WTO agreements are not

\footnotetext{
${ }^{121}$ ACJ Ruling 35-AN-2003.p.29.

122 ACJ Ruling 35-AN-2003.

${ }^{123}$ General Secretariat Resolution 596.

${ }^{124}$ Article 17 of the Treaty Establishing the Andean Court of Justice.
} 
part of such legal order. Additionally, in the Peru antidumping case, the General Secretariat erred in focusing on the obligation of the Andean states incurred under the WTO agreements without recognizing that its mandate was to ensure the fulfillment of Andean rules.

In sum, the obligations of the Andean Community members which are assumed within the framework of the international instruments that they individually signed are not the responsibility of the Andean Community. Therefore, none of its institutions should intervene in the manner in which these states live up to their international obligations, unless an infringement of community law exists. In any case, such international instruments signed by the Andean states provide for their own independent dispute settlement system that needs to be respected. Accepting the intervention of the Andean Community to oblige Andean states to comply with those independent international obligations or to sanction the noncompliance with those obligations may lead to a conflict of jurisdiction between the dispute settlement institutions of those international agreements and the Andean jurisdictional institution.

\section{Communitarization of WTO law in the Andean legal order}

\subsection{The approach of the legislative institutions of the Andean Community towards WTO law}

Since the establishment of the WTO, the institutional organs of the Andean Community have shown an interest in developing or maintaining consistency between Andean law and the international legal order represented by the WTO. In this respect, in 1995, the Andean Presidential Council instructed the Andean Commission to take into account the WTO agreements to reconcile the Andean legal order with the WTO law in different subject matters. The Andean Presidential Council also stressed the importance of encouraging actions aimed at developing common policies in order to attain the development of the productive sectors in the Andean Community. More importantly, in developing these policies, the Council pointed out that, among others, GATT/WTO law should be taken into account. ${ }^{125}$ There has since then been an implementation of some of the WTO obligations of the Member States of the Andean Community through the legislative system developed within the Andean Community.

Moreover, the Andean Community adopted the Andean Decision 458 which regulates its Common Foreign Policy. The Andean Member States have committed themselves to a strict respect of international law and the reinforcement of multilateralism. ${ }^{126}$ In the field of intellectual property rights, they pledged to maintain a common position based on Andean Community provisions and bearing in mind the commitments that they assumed internationally. ${ }^{127}$ One of the objectives of the Common Foreign Policy is to strengthen multilateralism. ${ }^{128}$ The concern for consistency of international agreements with Andean

125 Acta de Quito. VII Reunión del Consejo Presidencial Andino, Quito, Ecuador, September 5, 1995. Available at: http://www.comunidadandina.org/documentos/actas/act5-9-95.htm. (20.10.2014).

${ }^{126}$ Article 1 Section VI numeral 1 literal d) of the Andean Decision 458.

127 Article 1 Section VI numeral 2 literal i) of the Andean Decision 458.

${ }^{128}$ Article 1 Section II numeral 2 literal f) of the Andean Decision 458. 
law has also been present in the Andean legislative organs. For instance, the Andean Decision 486 which details the Common Intellectual Property Regime contains a provision allowing Andean states to negotiate industrial property cooperation agreements. Article 279 of the Decision stated that: "The Member Countries may sign cooperation agreements on intellectual property, such as the Patent Cooperation Treaty, provided that said agreements do not contravene the provisions of this Decision.”

It should be noted that Article 279 of the Andean Decision 486 cites the Patent Cooperation Treaty as an example of agreements that can be signed by the Member States. Therefore, it presupposes the compatibility of such a Treaty with the Andean legal order. However, the ACJ Ruling 14-AN-2001 amended this understanding, arguing that the Andean Commission has not been tasked with the function of enacting general rules to exempt Member States from potential infringements of the Andean legal order through the agreements that they signed with third parties which are contrary to Andean law. ${ }^{129}$ Consequently, the Andean legislative organs can endorse an international agreement and include it in the Andean legal order as they did with the WTO Agreement on Customs Valuation. Nevertheless, they cannot declare through secondary law that an international agreement subscribed to by the Member States is compatible with the Andean legal order since, as the ACJ claims, such a task should be performed by the ACJ on a case-by-case basis. As a consequence of the ACJ Ruling 14-AN-2001, the ACJ decided that the expression "such as the Patent Cooperation Treaty" should be deleted from Article 279 of the Andean Decision 486.

Within this framework, the Member States have negotiated in order to harmonize the Andean legal order with their obligations assumed within the WTO. In doing so, the legislative organs have adopted as an Andean norm some WTO provisions within the spheres of their competence. Modifications were made, for example, in the field of intellectual property rights which gave rise to the enactment of the Decision $486 .{ }^{130}$ The second transitional provision of the Andean Decision 486 makes reference to Article 27 of the TRIPS Agreement. It provides that "Microorganisms shall be patentable until other measures are adopted as a result of the examination provided for in TRIPS article 27 3b)." Articles 250 through 256 regulate border measures which were not included in the former Andean Intellectual Property Regime and respond to the regulation of these measures in the TRIPS Agreement. These provisions reflect the heightened interest of the legislative organs to make the necessary adjustments in order to be in line with the developments of the WTO rules. The Andean Decision 486 also incorporates some substantive rules of the TRIPS Agreement, such as the principle of national treatment ${ }^{131}$ and most-favored-nation treatment. ${ }^{132}$ Furthermore, the Andean institutions took into account the negotiations of the Uruguay Round while they were in the process of adopting new Andean rules. ${ }^{133}$

\footnotetext{
${ }^{129}$ ACJ Ruling 14-AN-2001.p.9-10.

${ }^{130}$ General Secretariat Resolution 476.

${ }^{131}$ Article 1 of the Andean Decision 486.

${ }^{132}$ Article 1 of the Andean Decision 486.

${ }^{133}$ Ecuador argued that when the Andean countries were negotiating the former Andean Decision 344 on intellectual property rights, the Andean countries made efforts to respect the TRIPS Agreement, which was in the final stage of its negotiation, by incorporating Article 27 of the said Agreement in Article 1 of Decision 344. See ACJ Ruling 34-AI-2001.p.39.
} 
In the same vein, the Preamble of Andean Decision 515 declares that the application of sanitary and phytosanitary measures applied by the Member States is to be consistent with the WTO norms. The principles enshrined in the Agreement on the Application of Sanitary and Phytosanitary Measures (SPS Agreement) were echoed in this Andean Decision. ${ }^{134}$ Likewise, Andean Decision 506 on the Recognition and Acceptance of Certificates of Products sold within the Andean Community requires the application of the definitions set forth in the WTO's Agreement on Technical Barriers to Trade (TBT Agreement) for the purposes of such Decision. ${ }^{135}$ Similarly, the Andean Decision 562 on guidelines for the drafting, adoption and application of technical regulations cites the TBT Agreement as the international framework for the elaboration, adoption and application of technical regulations. It accepts the notification procedure spelled out in Articles 2.9.2, 2.10.1, 5.6.2 and 5.7.1 and concludes that the notification procedure will be applied in accordance with Andean law and the TBT Agreement. ${ }^{136}$

With regard to safeguard measures on third countries, the Andean Community enacted Decision 452 of 1999. Article 2 a) of the Decision embodies the safeguard measures provided for in Article XIX of the GATT. The Preamble of the Decision states that it is necessary to develop community norms consistent with the Agreement establishing the WTO and the Agreement on Safeguards. It expresses the desire of the Andean Community to make the necessary adjustments to respect the WTO system. In addition, the Andean Community passed Decision 456 of 1999 on dumping practices originating in a Member State. Article 81 of this Decision mandates that the Agreement on Implementation of Article VI of the General Agreement on Tariffs and Trade 1994 (Antidumping Agreement) will be applied in a supplementary manner in all matters which are not laid down by the Decision. The Preamble of this Andean norm expresses that in order to accomplish the objectives of the regional integration in a context of openness, the improvement of community norms was required. The Antidumping Agreement was envisaged as one of the elements that should be taken into account in this regard. In respect of subsidies, the Andean Decision 457 of 1999 on subsidies and countervailing measures follows the same approach as that of Decision 456 and calls for the consistency of community law with the WTO Agreement on Subsidies and Countervailing Measures. The Decision refers to Article XVI of the GATT and defines the concept of subsidies in line with this provision. ${ }^{137}$ Similarly, the Agreement on Subsidies and Countervailing Measures will be applied in a supplementary manner in all matters which are not touched on by the Decision. ${ }^{138}$

Furthermore, there has been an incorporation of GATT/WTO law into the Andean Community legal order through the full endorsement of a WTO agreement. In December 12, 2003, the Commission of the Andean Community approved the Decision 571 which adopted the WTO Agreement on Implementation of Article VII of the General Agreement on Tariffs and Trade 1994 (Agreement on Customs Valuation) as the rule to govern the customs value of goods, along with the criteria developed in the Decision 571 and the

\footnotetext{
${ }^{134}$ See for instance Article 14 of the Decision 515.

${ }^{135}$ Article 1 of the Decision 506.

${ }^{136}$ Article 11 of the Decision 562.

${ }^{137}$ Article 8 of the Decision 457.

${ }^{138}$ Article 84 of the Decision 457.
} 
Resolution adopted by the General Secretariat on this matter. ${ }^{139}$ The Preamble of Decision 571 noted that the Andean Community states are members of the WTO and are bound by the Agreement on Customs Valuation. It should be noted that prior to the Decision 571, the former Andean rules on custom valuation also contained the adoption of the WTO Agreement on Customs Valuation. ${ }^{140}$ The General Secretariat Resolution 1239 lays down the conditions and terms for the application of the Andean Value Declaration and aims at harmonizing the documentation that is required to submit evidence of the value at customs. This Resolution echoes the approach of Decision 571 concerning the Agreement on Customs Valuation and, in this respect, the Andean Value Declaration intends to support the correct application of this WTO Agreement. ${ }^{141}$ Hence, this WTO Agreement became the legal standard with which Andean states must comply. It is noteworthy that this legislative practice has also been established with respect to other international norms. For instance, Article 151 of the Andean Decision 486 directs Member States to apply the 1957 Nice Agreement Concerning the International Classification of Goods and Services for the Purposes of the Registration of Marks, including its updated amendments. As regards this Agreement, the ACJ has clarified that pursuant to the said Andean Decision (the ACJ quoted ex-Article 101 of the former Andean Decision 344) such Agreement is not merely a reference but rather is mandatory for all the Member States. ${ }^{142}$

In sum, the number of incorporations of WTO rules and commitments conveys that the Andean Community has been receptive to the multilateral trading system.

\subsection{The approach of the Andean Community Court of Justice concerning the interpretation and application of WTO rules incorporated by Andean law}

In a case brought against Bolivia before the ACJ for noncompliance with the former Andean Decisions 378 and 379, the ACJ referred to Article 1 of Decision 378 which, like the current Decision 571, also called upon Member States to apply the WTO Agreement on Customs Valuation along with Andean Decisions for customs value of goods purposes. The ACJ found that Bolivia failed to apply Andean Decisions 378 and 379 by delaying its application. $^{143}$ Therefore, since the WTO Agreement on Customs Valuation was incorporated by the Andean Decision, Bolivia was also failing to apply this Agreement which was part of the Andean legal order. Such conduct constituted an infringement of the Andean legal order.

The ACJ had the chance to address the application of the WTO Agreement on Customs Valuation in 2009. In its Ruling 44-IP-99, the ACJ interpreted this WTO Agreement and claimed that such Agreement had to be applied by virtue of the Andean Decision 571. Although the ACJ quoted its case law on the principle of supremacy, the Court did not elaborate further on the question of the relationship between the WTO Agreement on Customs Valuation and the Andean legal order as it did in its subsequent ruling concerning

\footnotetext{
139 Articles 1, 2, 3 and 4 of the Decision 571.

${ }^{140}$ Andean Community Decision 378 and 379.

${ }^{141}$ Preamble of the General Secretariat Resolution 1239.

${ }^{142}$ ACJ Ruling 10-IP-94.p.14, 19.

143 ACJ Ruling 8-AI-2008.p.9.
} 
the same Agreement. ${ }^{144}$ Additionally, the ACJ did not assert that there was a communitarization of a WTO rule. In fact, this term was coined in its Preliminary Ruling 03-IP-2014 which will be reviewed below.

Recent development in the ACJ case law on the question of the implications of the adoption of WTO agreements in the Andean legal order shows a Court, again, concerned over the application of the Andean legal order. In its Preliminary Ruling 03-IP-2014, the ACJ observed that there is a relationship between WTO law and the Andean Community rules and began the analysis of such relationship by discussing the prevalence of the latter over the international agreements signed by the Andean states; however, it merely recited its previous case law. ${ }^{145}$ This was the first point addressed by the ACJ when, interestingly, there was no alleged conflict between the legal systems. In this communitarization case, the ACJ put emphasis on the supremacy of Andean law. The Court's concern over the application of Andean law is demonstrated even more clearly in its approach to the WTO Agreement on Customs Valuation incorporated in the Andean legal order. In essence, the ACJ focused on the hierarchal relationship between these two legal systems and confirmed its previous case law on the prevalence of Andean law over WTO rules. ${ }^{146}$ Why does the ACJ overstate the supremacy of Andean law in this type of case? The order of analysis of the ACJ is illustrative. It can be argued that the ACJ wanted to make clear that despite the communitarization of WTO rules, the Member States must always abide by the Andean legal order and the application of the WTO rules will take place so long as the Andean legal order itself has included such rules.

After affirming the supremacy of Andean law, the ACJ again cited its previous case law and reiterated two points: the autonomous nature of the Andean legal order, and the lack of direct effect of WTO rules. ${ }^{147}$ It then continued to add that the referring national court should apply Community law in preference to the norms of international law subscribed to by the Member States. It further concluded that such application of international law should be done in a field in respect of which the Andean Community has not yet legislated so long as such norms do not contradict the Andean legal order. ${ }^{148}$ Only after these observations did the ACJ declare that there had been a communitarization of the WTO Agreement on Customs Valuation, namely that this WTO Agreement has been included by Andean law itself and therefore has become part of the Andean legal order. ${ }^{149}$ This case reveals that the ACJ continues to issue mostly narrow rulings concerning the direct effect of international agreements. In essence, instead of reaffirming that WTO agreements lack direct effect, the ACJ could have seized the opportunity to specify that since the WTO Agreement on Customs Valuation is part of the Andean legal order through incorporation, it has, like any other Andean rule, direct effect and takes precedence over Member States' law in contrast to its previous case law which excluded the WTO rules from the Andean legal order. Nevertheless, neither of these two aspects were declared by the ACJ.

\footnotetext{
144 ACJ Ruling 44-IP-2009.

145 ACJ Ruling 03-IP-2014 para.34.

146 ACJ Ruling 03-IP-2014 para.35-36.

147 ACJ Ruling 03-IP-2014 para.38.

148 ACJ Ruling 03-IP-2014 para.39.

149 ACJ Ruling 03-IP-2014 para. 40-41.
} 
Moreover, the ACJ instructed the national judge to apply this multilateral agreement following the harmonic interpretation provided for by the ACJ. Explicitly, the ACJ reserved the right to interpret this communitarized WTO Agreement. ${ }^{150}$ Consequently, the ACJ left no room for the national court to refer to the rulings of the WTO Panels and Appellate Body when such provisions have been subject to interpretation. The national court is bound to apply the communitarized WTO rule and, in the event of any doubt about the scope of such a rule it will have to refer the case via preliminary ruling to the ACJ. The national court will always have to apply the ACJ interpretation even in the event of a different interpretation provided by the WTO Panels and Appellate Body. In this regard, this ruling yields no information as to whether the ACJ will look at the WTO Panels and Appellate Body reports for guidance when interpreting a communitarized WTO rule.

It is noteworthy that the ACJ has acknowledged in its earlier case law that the harmonization of Andean legislation with international agreements was the task of the legislative organs of the Andean Community which would include the debate over the political decision on whether this harmonization is convenient or not for the community interests and objectives. ${ }^{151}$ In this case, the ACJ went on to emphasize its obligation to achieve through interpretation a harmonization between Andean law and the communitarized multilateral rule in the light of the fundamental principles that guide Andean Community law. ${ }^{152}$ In any case, the WTO Customs Valuation has been included in the Andean Decision 571 and as a consequence thereof, it has acquired the rank of Community law in the Member States' legal orders. Consequently, it should be interpreted as any other provision of the Andean legal order whose uniform application and interpretation in all the Member States the ACJ is bound to ensure.

Furthermore, the ACJ has no legal basis for finding that an Andean Member has breached a WTO provision independent of a violation of an Andean provision. Only in the case of a communitarized WTO rule may the ACJ declare the violation of a WTO rule that is part of the Andean legal order.

Looking at these cases where the ACJ had the opportunity to discuss the relationship between Andean and WTO law, and taking into account the course pursued by the ACJ in the communitarization case, it becomes clear that the ACJ purports to avoid any confusion about the hierarchy and position of Andean law. The reason for the permanent affirmation afforded by the ACJ, in particular when a question of the application of WTO rules arises, might simply have to do with its view on the need to protect the identity and integrity of the Andean legal order from the WTO. Indeed, the ACJ has a certain tendency to adopt a more integrationist approach.

On the other hand, the ACJ's rulings have influenced and shaped secondary law. For example, the ACJ declared void Article 1 of Decision 486 which recognized that national treatment shall be extended for the nationals of the Paris Convention and WTO members. In the same vein, the ACJ sanctioned the nullity of Article 2 of the said Andean Decision which extended the application of most-favored-nation treatment to the nationals of the

\footnotetext{
${ }^{150}$ ACJ Ruling 03-IP-2014 para. 40.

${ }^{151}$ ACJ Ruling 89-AI-2000.

${ }^{152}$ ACJ Ruling 03-IP-2014 para.40.
} 
Paris Convention and WTO members. The ACJ correctly interpreted Articles 75 and 139 of the Cartagena Agreement (ex-Articles 74 and 155, respectively) and concluded that any modification must be carried out through a treaty reform. Interestingly, the ACJ also resorted to the exceptions laid down by the GATT/WTO concerning regional trade agreements to assert that the benefits granted among Andean countries did not have to be extended to third countries. ${ }^{153}$ Arguably, taking into account the Ruling 14-AN-2001 delivered by the ACJ, in the event of an incorporation of a WTO agreement or provision through secondary law enacted by the legislative organs of the Andean Community, the ACJ may examine the compatibility of such communitarized WTO rule with the Cartagena Agreement. In the event of any inconsistency, the ACJ may declare the nullity of a communitarized WTO rule.

\section{Concluding remarks}

The WTO agreements have no place in the Andean legal hierarchy as they are not part of the Andean legal order. Neither are they directly effective in the Andean Community.

Drawing upon the case law reviewed, this study reflects that the possibility to invoke WTO rules before the ACJ describes the particular challenges faced by this Court. The ACJ resolves the possible norm collisions within legal orders with an invariable declaration of the principle of supremacy of Andean law in all cases. In this connection, the ACJ expresses that there is no need even to declare such a conflict since Andean law will always prevail and be applied. On the other hand, the ACJ has not clearly and properly elaborated upon the question of the use of WTO law as the basis for illegality of Andean law. The ACJ has succumbed to its worries for the applicability of Andean law to the extent that instead of analyzing the direct effect argument in detail, it has proclaimed the supremacy of Andean law. The Court should clarify its jurisprudence relating to the direct effect of WTO agreements.

The perceived applicability of WTO rules in the Andean legal order varies across the Andean institutions. The General Secretariat's approaches and the ACJ differ from the manner in which they are willing to review WTO law. Whereas the General Secretariat shows its intention to engage in an interpretation of Andean law in the light of the WTO agreements, declare the compatibility between both legal systems and demand Member States live up to their WTO obligations, the ACJ has refused the idea that Andean institutions act as enforcers of WTO law.

The ACJ has shown its willingness to tailor the interpretation of Andean law so as to take into consideration international agreements signed by the Member States. However, the ACJ has constantly defended the autonomy of the Andean legal system. This paper illustrates that the constant reaffirmation of supremacy of Andean over WTO rules may have stemmed from a sense of strengthening Andean integration to the extent that Andean countries are bound to ensure the direct application and direct effect, as well as the supremacy of Andean rules over any other legal system.

\footnotetext{
${ }^{153}$ ACJ Ruling 14-AN-2001.p.8-9.
} 